\title{
A double immunofluorescent method for simultaneous analysis of progesterone-dependent changes in proliferation and the oestrogen receptor in endometrium of rhesus monkeys
}

\author{
W. C. Okulicz and M. Balsamo \\ Department of Obstetrics and Gynecology, University of Massachusetts Medical School, Worcester, \\ MA 01655, USA
}

\begin{abstract}
A double immunofluorescent technique that permitted the nuclear localization of both the oestrogen receptor and the Ki-67 antigen (marker of cell proliferation) within the same tissue section was developed and used to determine the relationship between the oestrogen receptor and proliferation within the major zones of the primate endometrium. Endometrial tissue was obtained from ovariectomized rhesus monkeys in which the hormonal pattern of oestradiol and progesterone was simulated with Silastic implants containing each hormone. The oestrogen receptor was detected using the $\mathrm{H} 222$ rat monoclonal antibody and Texas Red conjugated streptavidin. Immunofluorescent staining of a mouse monoclonal antibody to the $\mathrm{Ki}-67$ antigen was detected by an antibody to mouse IgG conjugated with fluorescein isothiocyanate. Primary antibodies were co-incubated with tissue sections followed by sequential detection of the oestrogen receptor and Ki-67. A dual wavelength filter was used to monitor simultaneously both immunofluorescent patterns. Application of this technique to study regulation of endometrial proliferation and oestrogen receptor content by progesterone showed that the endometrium exhibited two different responses to progesterone: luminal and glandular epithelia and stromal cells in the functionalis and zone III of the basalis showed coincident decreases of oestrogen receptor and proliferation, whereas the oestrogen receptor in glandular epithelia of zone IV (basalis) was not downregulated and there was an increase in proliferation.
\end{abstract}

\section{Introduction}

The primate endometrium is a complex tissue composed of various types of cell (luminal and glandular epithelia, stromal fibroblasts, vascular smooth muscle cells) that are targets either directly or indirectly for the female sex steroids oestradiol and progesterone. In addition, there is a horizontal zonation in both rhesus and human endometrium that is defined by histologic criteria (Bartelmez et al., 1951): the transient functionalis consists of zone I (luminal epithelia and associated stroma) and zone II (upper third of the glands); the germinal basalis consists of zone III (middle third of the glands) and zone IV (the most basal segments of the glands).

The response of the endometrium to oestradiol is governed primarily by specific high-affinity receptors that act as transcription factors to activate specific genes and gene networks (Yamamoto, 1985; Evans, 1988). Several studies have shown that progesterone downregulates the oestrogen receptor in the rodent uterus (Okulicz ef al., 1981; Okulicz, 1987, 1989) and primate endometrium (Press et al., 1984; McClellan et al., 1986; Okulicz et al., 1990). Because a limiting concentration of a transcription factor may lead to gene inactivation, the downregulation of the oestrogen receptor by progesterone is

Received 11 January 1993. considered an important mechanism whereby oestrogen action is inhibited, redirected or reduced. In addition, it has been shown that different types of cell within the endometrium respond in different ways to the same hormonal stimulus (King et al., 1980; McCormack and Glasser, 1980). To study the responses of different types of cell in the endometrium, we and other groups have used immunohistochemical analyses (McClellan et al., 1984; Press et al., 1984; Perrot-Applanat et al., 1985; Clarke et al., 1987; Korach et al., 1988; Okulicz et al., 1989). We have previously shown that endometrial stromal cells are more sensitive to downregulation of the oestrogen receptor by progesterone than are glandular epithelial cells, and that the oestrogen receptor in glandular epithelia of zone IV in the endometrial basalis is not downregulated by progesterone (Okulicz et al., 1990).

The effect of oestrogen on the endometrium is to enhance cell growth (proliferative phase of the menstrual cycle), whereas progesterone inhibits proliferation and induces differentiation of various types of endometrial cell (secretory phase) (Maslar, 1988). To study the relationship of downregulation of the oestrogen receptor by progesterone and inhibition of proliferation in the endometrium of rhesus monkeys by progesterone, we developed a double immunofluorescent technique to detect both the oestrogen receptor and the $\mathrm{Ki}-67$ antigen (a nuclear marker of cell proliferation) with specific monoclonal antibodies 
Table 1. Oestradiol and progesterone concentrations on days 13, 14, 17 and 21 during artificial menstrual cycles in rhesus monkeys

\begin{tabular}{lcc}
\hline Day & $\begin{array}{c}\text { Oestradiol } \\
\left.(\mathrm{nmol})^{-1}\right)\end{array}$ & $\begin{array}{c}\text { Progesterone } \\
\left.(\mathrm{nmol} \mathrm{I})^{-1}\right)\end{array}$ \\
\hline 13 & $0.89 \pm 0.11$ & $<0.2$ \\
14 & $0.24 \pm 0.05$ & $5.7 \pm 1.7$ \\
17 & $0.31 \pm 0.07$ & $16.6 \pm 3.7$ \\
21 & $0.21 \pm 0.02$ & $27.8 \pm 3.4$ \\
\hline
\end{tabular}

All values are means $\pm \operatorname{SEM}, n=4$.

in endometrial tissue sections. This approach allowed the simultaneous identification of those cells that are proliferating and contain the oestrogen receptor and those cells that are proliferating and do not contain the oestrogen receptor.

\section{Materials and Methods}

\section{Animals}

Menstrual cycles were induced in ovariectomized rhesus monkeys by the timed insertion and removal of Silastic implants containing either oestradiol or progesterone as described by Longcope et al. (1988) and Okulicz et al. (1990). Artificial menstrual cycles were induced because it is difficult to obtain precisely timed biopsies during the changeover from dominance by oestrogen (day 13) to progesterone (day 21). Animals were between 5 and 9 years of age and weighed between 3.5 and $6 \mathrm{~kg}$. Endometrial biopsy tissue was obtained at hysterectotomy as described by Padykula et al. (1984) on days 13 (peak oestradiol), 14, 17 and 21 (peak progesterone). Concentrations of oestradiol and progesterone in plasma were measured by radioimmunoassay as described by Longcope et al. (1974, 1988) (Table 1). All protocols were approved by the Institutional Animal Care and Use Committee. Tissue samples were oriented in small aluminum foil cups and frozen immediately in Tissue Tek OCT embedding compound (liquid nitrogen). Samples were subsequently stored at $-80^{\circ} \mathrm{C}$.

\section{Double immunofluorescent analysis}

Cryostat $\left(-27^{\circ} \mathrm{C}\right)$ sections $(6 \mu \mathrm{m})$ were fixed in freshly prepared $4 \%$ paraformaldehyde in phosphate-buffered saline (PBS) $\left(0.1 \mathrm{~mol} \mathrm{l}^{-1}\right.$ ) $\mathrm{pH} 7.4$ for $15 \mathrm{~min}$ at $4^{\circ} \mathrm{C}$. Sections were washed twice in PBS for $15 \mathrm{~min}$. All subsequent incubations with immunochemicals were performed in a humidified chamber.

Monoclonal antibodies to the human oestrogen receptor (H222) and the Ki-67 antigen (proliferating cell marker (Gerdes et al., 1983, 1984)) were obtained commercially from Abbott Laboratories (North Chicago, IL) and Transbio (Paris), respectively. Rat (oestrogen receptor) IgG $A B C$ kits were obtained from Vector Labs (Burlingame, CA). Streptavidin-conjugated Texas Red and anti-mouse IgG conjugated with fluoroscein isothiocyanide (FITC) were obtained from Amersham Co.
(Arlington Heights, IL). Sections were co-incubated with the oestrogen receptor antibody (1:2 in PBS) and the Ki-67 antibody $(\mathrm{I}: 30)$ overnight $(16-18 \mathrm{~h})$ at $4{ }^{\circ} \mathrm{C}$. Control tissue sections were co-incubated with preimmune rat $\operatorname{IgG}$ and preimmune mouse IgG. After incubation with primary antibodies, sections were washed twice in PBS for $10 \mathrm{~min}$ at room temperature. Detection of the oestrogen receptor and $\mathrm{Ki}-67$ was performed sequentially: the oestrogen receptor was detected by the avidin-biotin complex $(A B C)$ technique using Texas Redconjugated streptavidin. After two washes in PBS, the sections were incubated for $45 \mathrm{~min}$ with anti-mouse IgG conjugated with FITC, followed by two washes in PBS and a final wash in glass distilled water. Excess water was removed and slides were mounted with Gel/Mount (Biomedia Corp., Foster City, CA). Incident-light fluorescence was monitored with an Axioskop microscope (Carl Zeiss, Oberkocken) equipped with a dual wavelength filter (Omega Optical, Inc., Brattleboro, VT) to permit simultaneous detection of Texas Red and FITC fluorescence. Ektachrome 400 film (Eastman-Kodak, Rochester, NY) was used for photomicroscopy and cibacron prints were made from slides.

Several controls in addition to preimmune sera were used to establish the validity of the technique: crossreactivity of the mouse secondary antibody with the rat oestrogen receptor primary antibody was tested by omission of the rat secondary antibody, Texas Red and Ki-67 antibody; crossreactivity of the mouse secondary antibody with rat secondary antibody was tested by the omission of Texas Red conjugated streptavidin and $\mathrm{Ki}-67$ antibody; nonspecific binding of secondary antibodies was tested in the absence of each primary antibody. No background fluorescence was observed with the above controls (data not shown).

\section{Results}

The oestrogen receptor and $\mathrm{Ki}-67$ antigens are primarily localized in the nucleus (Fig. I). When the same tissue section is viewed with a dual wavelength filter for Texas Red and FITC (Fig. 1, day 13 zone I), endometrial cells that exhibit coincident staining for the oestrogen receptor and $\mathrm{Ki}-67$ contain yellow-orange nuclei. As shown on day 13 (Fig. I) in zones II-III and IV, cell nuclei that do not stain for $\mathrm{Ki}-67$ but possess the oestrogen receptor are red. On day 13 , the predominant proliferation in the endometrium resides in zones I and II-III and a much smaller proportion of cells proliferate in zone IV. All cells that show evidence of proliferation also contain the oestrogen receptor on day 13 (peak oestradiol).

On day 14 (Fig. 1), there is a slight decrease in proliferation in zones II-III. Proliferation in zone IV remains low. All proliferating cells contain the oestrogen receptor. However, by day 17 (Fig. 2), there is a dramatic shift in proliferation and cells containing oestrogen receptors throughout the endometrium. Not only is there a downregulation of the oestrogen receptor in zones I and II-III in response to rising plasma progesterone, but there is also a coincident decrease in the proliferating cell population. These effects are apparent in luminal and glandular epithelia and stromal cells. The few cells that continue to proliferate in these endometrial zones contain little or no oestrogen receptor (green nuclei). A similar pattern 

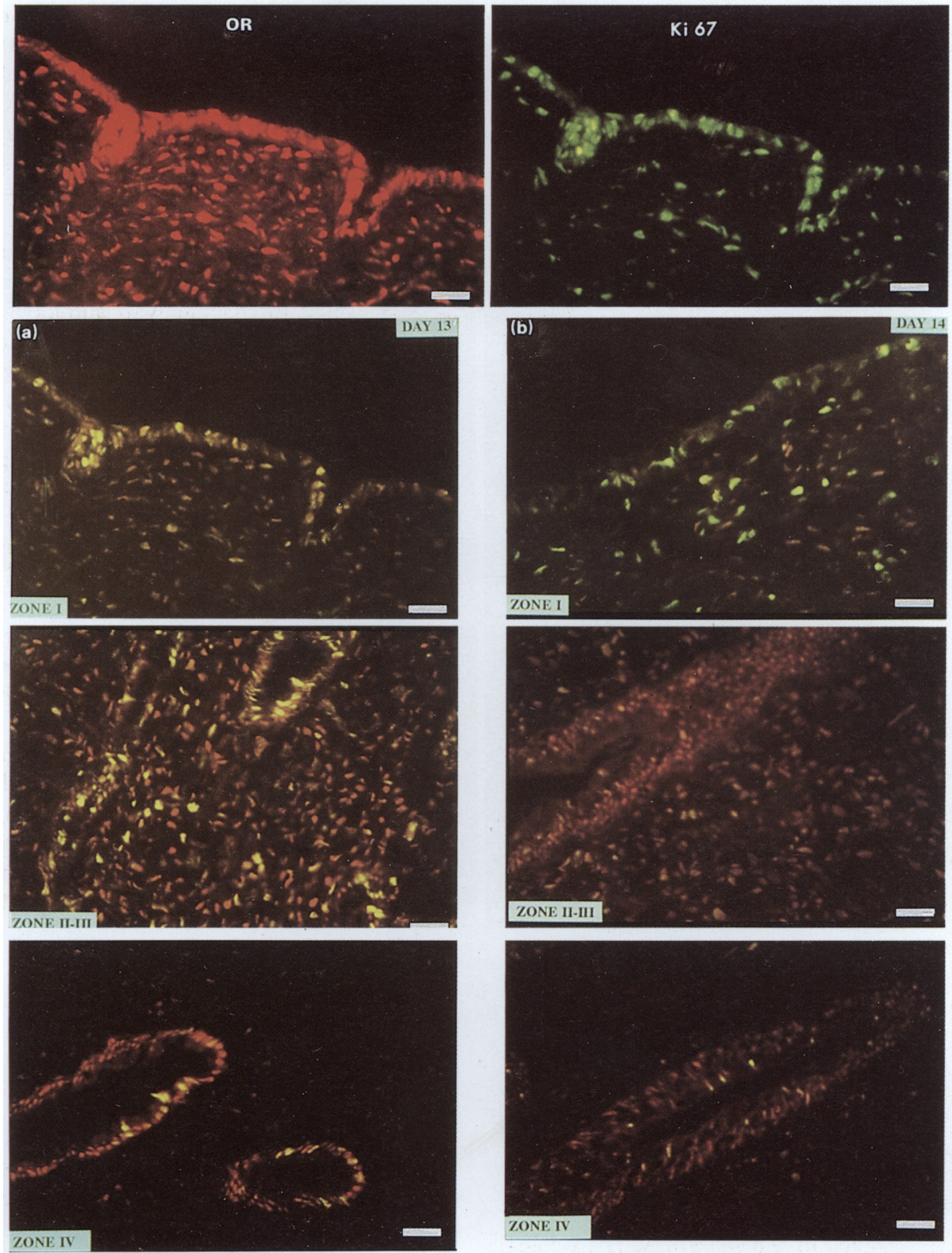

Fig. 1. Double immunofluorescent analysis of the oestrogen receptor (OR) and $\mathrm{Ki}-67$ antigen in endometrial tissue harvested on (a) day 13 and (b) day 14 of artificial menstrual cycles in rhesus monkeys. The upper panel shows Texas Red fluorescent detection of the oestrogen receptor and fluorescein isothiocyanate (FITC) detection of the Ki-67 antigen with fluorescent filters specific for each fluorochrome. Zone I of day 13 tissue is the same tissue section viewed with a dual wavelength filter set to detect both Texas Red and FITC. Data shown are representative from four animals. Scale bars represent $50 \mu \mathrm{m}$.

of oestrogen receptor downregulation and associated decrease in the proliferating cell population is also apparent on day 21 (peak progesterone).

In contrast to the decrease in proliferating cell population observed in zones I and II-III on days 17 and 21 , there is an increase in proliferation in the glandular epithelia of the basalis zone IV (Fig. 2). In addition, the glandular epithelia of zone IV maintain the oestrogen receptor. All proliferating cells in the glandular epithelia of zone IV contain immunoreactive oestrogen receptor (yellow/orange).

\section{Discussion}

The cyclic hormonal control mechanisms that regulate endometrial growth and differentiation are driven by the female 

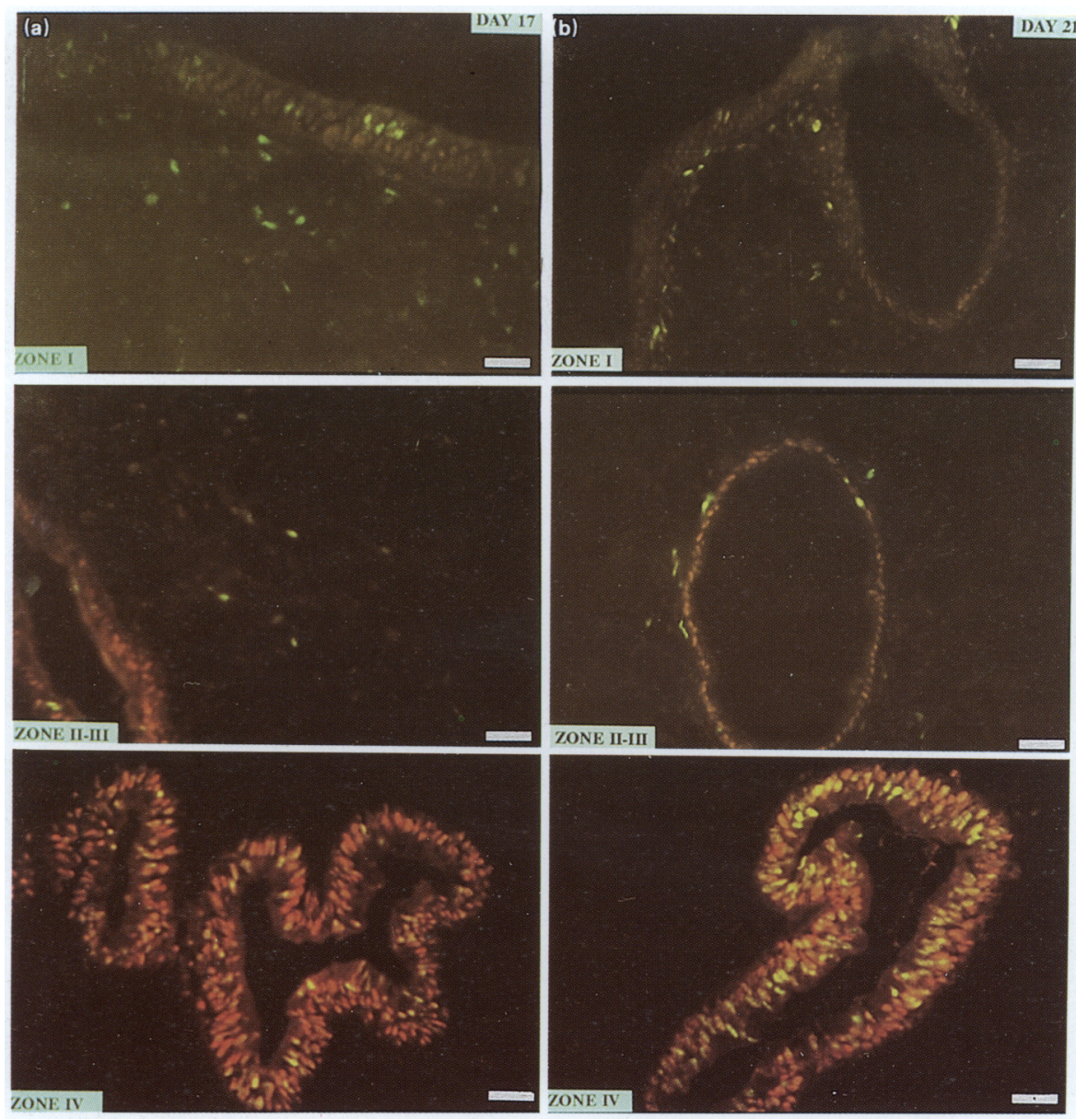

Fig. 2. Double immunofluorescent analysis of the oestrogen receptor and Ki-67 antigen in endometrial tissue harvested on (a) day 17 and (b) day 21 of artificial menstrual cycles in rhesus monkeys. Data shown are representative from four animals. Scale bars represent $50 \mu \mathrm{m}$.

sex steroids oestradiol and progesterone. Oestradiol promotes uterine cell growth and primes the uterus for progesterone action by an upregulation of progesterone receptors. Progesterone promotes the differentiation of endometrial cells and prepares the endometrium for potential implantation. In concert with progesterone-dependent differentiation, there is a concomitant inhibition of proliferation and downregulation of the oestrogen receptor. In the study reported here, we developed a double immunofluorescent technique to study the relationship of oestrogen receptor downregulation and the proliferating cell population (Ki-67, proliferating cell marker). Because both antigens are primarily nuclear proteins, we took advantage of the fact that each monoclonal antibody was made in a different species. The oestrogen receptor antibody $(\mathrm{H} 222)$ was produced in rat and the $\mathrm{Ki}-67$ is a mouse monoclonal. Thus, speciesspecific secondary antibodies could be used that do not crossreact with the other primary antibody, e.g. anti-mouse IgG that does not crossreact with rat $\operatorname{IgG}$ or anti-rat IgG. In this manner, cells that contain the oestrogen receptor and are not proliferating would have red nuclei (Texas Red) and those cells that were proliferating and did not contain the oestrogen receptor would have green nuclei. Cells that contain both antigens (the oestrogen receptor and the proliferation cell marker) appear yellow-orange.
Our results showed that during the late proliferative phase (day 13) of artificial menstrual cycles in the rhesus monkey, all cells that were proliferating contained the oestrogen receptor. The proliferating cell population was primarily located in zones I and II-III of the endometrium and only a few glandular epithelial cells were proliferating in zone IV. The initial stage of the secretory phase (day 14) showed only minor changes in proliferation and cells containing oestrogen receptors. Downregulation of the oestrogen receptor by progesterone was evident on day 17 and day 21 in zones I and II-III. These data on progesterone regulation of the oestrogen receptor are similar to those reported previously by McClellan et al. (1986), Press et al. (1986) and Okulicz et al. (1990). Because the downregulation of the oestrogen receptor and the proliferating cell marker Ki-67 were coincident, there appears to be a strong relationship between the maintenance of proliferation and the presence of the immunoreactive oestrogen receptor. Thus, these data suggest that inhibition of proliferation by progesterone is closely associated with downregulation of the oestrogen receptor by progesterone.

The deepest portion of the endometrium, zone IV, has been shown to respond in a different way from the upper regions of the endometrium to the same hormonal stimuli (Padykula et al., 1984, 1989). In the present study our results showed that the Downloaded from Bioscientifica.com at 04/26/2023 01:57:30PM 
proliferating cell population in glandular epithelial cells of zone IV increases during the secretory phase. These data using the $\mathrm{Ki}-67$ antigen as a marker for the proliferating cell population mirror previous results obtained with in vivo $\left[{ }^{3} \mathrm{H}\right]$ thymidine uptake in rhesus endometrium during the secretory phase (Padykula et al., 1989). The results reported here suggest that progesterone is acting as a mitogen either directly or indirectly (autocrine/paracrine factors) on glandular epithelial cells of zone IV. The proliferation observed in the basalis zone IV may, in part, provide the stem/progenitor cells necessary for postmenstrual reconstruction.

Glandular epithelia in zone IV are also distinguished by the maintenance of immunoreactive oestrogen receptor during progesterone dominance. Despite the downregulation of the oestrogen receptor throughout the other regions of the endometrium glandular epithelia, downregulation by progesterone did not occur in zone IV. These cells also contain the progesterone receptor, despite a downregulation of the progesterone receptor in glandular epithelia in zones I and II-III (Press et al., 1988; Okulicz et al., 1990). Thus, glandular epithelia of zone IV do not appear to respond to progesterone by three criteria: proliferation is not inhibited; oestrogen receptor is not downregulated; and the progesterone receptor is not downregulated.

The effect of a hormone on a target tissue is most often described as an integral of the response to all cells within a target tissue. However, in the study reported here and in previous work, it has become clear that different cells or types of cell within a target tissue can respond in a different way to the same hormonal stimuli. These results strongly support the concept that the primate endometrium contains distinct microenvironments that can respond in different ways to the same hormonal stimulation and that different types of cell within the endometrium also show different responses.

The authors thank L. Fortier, C. Longcope and J. Tast for their help and support of this work. This work was supported by a grant from the NIH (HD 20290).

\section{References}

Bartelmez GW, Corner GW and Hartman CG (1951) Cyclic changes in the endometrium of the rhesus monkey (Macaca mulatta) Contributions to Embryology 34 99-144

Clarke CL, Zaino RJ, Feil PD, Miller JV, Steck ME, Ohlsson-Wilhelm BM and Satyaswaroop PG (1987) Monoclonal antibodies to human progesterone receptor: characterization by biochemical and immunohistochemical techniques Endocrinology 121 1123-1132

Evans RM (1988) The steroid and thyroid hormone receptor superfamily Science 240 889-895

Gerdes J, Schwab U, Lemke H and Stein H (1983) Production of a mouse monoclonal antibody reactive with a human nuclear antigen associated with cell proliferation International Joumal of Cancer 31 13-20

Gerdes J, Lemke $\mathrm{H}$ and Baisch $\mathbf{H}$ (1984) Cell cycle analysis of a cell proliferationassociated human nuclear antigen defined by the monoclonal antibody Ki-67 Journal of Immunology 133 1710-1715
King RJB, Dyer G, Collins WP and Whitehead MI (1980) Intracellular estradiol, estrone and estrogen receptor levels in endometria from postmenopausal women receiving estrogens and progestins Journal of Steroid Biochemistry 13 $377-382$

Korach KS, Horigome T, Tomooka Y, Yamashita S, Newbold RR and McLachlan JA (1988) Immunodetection of estrogen receptor in epithelial and stromal tissues of neonatal mouse uterus Proceedings of the National Academy of Sciences USA 85 3334-3337

Longcope C, Watson D and Williams KIH (1974) The effects of synthetic estrogens on the metabolic clearance and production rates of estrone and estradiol Steroids 24 15-30

Longcope C, Bourget C, Meciak PA, Okulicz WC, McCracken JA, Hoberg LM and Padykula HA (1988) Estrogen dynamics in the female rhesus monkey Biology of Reproduction 39 561-565

McClellan MC, West NB, Tacha DE, Greene GL and Brenner RM (1984) Immunocytochemical localization of estrogen receptors in the macaque reproductive tract with monoclonal antiestrophilins Endocrinology $\mathbf{1 1 4}$ 2002-2014

McClellan MC, West NB and Brenner RM (1986) Immunocytochemical localization of estrogen receptors in the macaque endometrium during the luteal-follicular transition Endocrinology 119 1467-1475

McCormack SA and Glasser SR (1980) Differential response of individual uterine cell types from immature rats treated with estradiol Endocrinology 106 1634-1649

Maslar IA (1988) The progestational endometrium Seminars in Reproductive Endocrinology 6 115-128

Okulicz WC (1987) Effect of the antiprogestin RU-486 on progesterone inhibition of occupied nuclear estrogen receptor in the uterus Journal of Steroid Biochemistry 28 117-122

Okulicz WC (1989) Temporal effects of progesterone inhibition of occupied nuclear oestrogen receptor retention in the rat uterus Joumal of Endocrinology 121 101-107

Okulicz WC, Evans RW and Leavitt WW (1981) Progesterone regulation of the occupied form of nuclear estrogen receptor Science 213 1503-1505

Okulicz WC, Savasta AM, Hoberg LM and Longcope C (1989) Immunofluorescent analysis of estrogen induction of progesterone receptor in the rhesus uterus Endocrinology 125 930-934

Okulicz WC, Savasta AM, Hoberg LM and Longcope C (1990) Biochemical and immunohistochemical analyses of estrogen and progesterone receptors in the rhesus monkey uterus during the proliferative and secretory phases of artificial menstrual cycles Fertility and Sterility 53 913-920

Padykula HA, Coles LG, McCracken JA, King NW, Longcope $C$ and KaisermanAbramof IR (1984) A zonal pattern of cell proliferation and differentiation in the rhesus endometrium during the estrogen surge Biology of Reproduction 31 1103-1118

Padykula HA, Coles LG, Okulicz WC, Rapaport SI, McCracken JA, King NW Jr, Longcope C and Kaiserman-Abramof IR (1989) The basalis of the primate endometrium: a hormonally responsive bifunctional germinal compartment Biology of Reproduction 40 681-690

Perrot-Applanat M, Logeat F, Groyer-Picard MT and Milgrom E (1985) Immunocytochemical study of mammalian progesterone receptor using monoclonal antibodies Endocrinology 116 1473-1484

Press MF, Nousek-Goebl N, King WJ, Herbst AL and Greene GL (1984) Immunohistochemical assessment of estrogen receptor distribution in the human endometrium throughout the menstrual cycle Laboratory Investigations 51 495-503

Press MF, Nousek-Goebl N, Bur M and Greene GL (1986) Estrogen receptor localization in the female genital tract American Joumal of Pathology 123 280-292

Press MF, Udove JA and Greene GL (1988) Progesterone receptor distribution in the human endometrium American Journal of Pathology 131 112-124

Yamamoto K (1985) Steroid receptor regulated transcription of specific genes and gene networks Annual Review of Genetics 19 209-252 